\title{
Research on Enterprise Economic Management Mode from the Perspective of Marketing
}

\author{
Qu Yining \\ Liaoning Institute of Mechatronic Technology
}

Keywords: Enterprises; Marketing; Economic Management; Innovation

\begin{abstract}
. this paper focuses on the problems existing in the enterprise economic management and discusses the innovation of the enterprise economic management model under the marketing angle from four aspects, such as strengthening the management of human resources training mechanism, perfecting the economic management system, etc. Some reference and suggestions are provided to improve the comprehensive competitiveness of the enterprise market and economic management capabilities
\end{abstract}

\section{The main problems in the economic management of enterprises}

\subsection{Lack of human resources incentives}

Concerning the distribution and structure of human resources personnel in enterprises, the distribution of human resources personnel is scattered and the institutional set up is unreasonable. As one of the basic departments of the enterprise, the human resources department is also an important department to ensure the orderly operation of the internal working mechanism of the enterprise as well. However, the overall quality of the staff in majority of the human resources departments is low with insufficient professional management capacity, especially the internal human resources management staff lacking awareness of management and responsibility.

In the development of talent training, some enterprises did not actively introduce incentive mechanisms and lack the effective approaches to communication and management, which further reduce the comprehensive competitiveness of enterprises in the market competition. Incentive mechanism is a scientific and effective internal talent management model, which is mainly used to enhance the enthusiasm and initiative of employees to achieve the goal of comprehensively improving the personal quality and comprehensive ability of employees. However, due to the existence of various factors, most enterprises have a series of problems, such as the constant personnel changes, greater staff mobility, frequent changes of economic management personnel, the failure of coordination of personnel transfer work, etc., which further leads to the inefficiency of the internal economic management, the inflexibility and diversity of the management methods.

\subsection{Lack of pertinence and substantiality of the management system}

At present, most enterprises focus on project capital investment and expanding of the market share, thus seriously the internal economic management has been neglected. The economic management system set by the enterprise itself has not been formulated conforming to their own actual situation and lacks the pertinence of the management system. Even some enterprises will establish the economic management system as a form of handling the inspection from relevant departments, which is not substantial. In addition, due to the low quality of the enterprise's economic management staff and the lack of awareness of responsibility and management, the economic management work of the enterprise industry cannot be fully realized. It is impossible to give full play to the role and effect of enterprise economic management system and management work. The defects of the economic management system and the weak sense of responsibility of the managers ultimately lead to the low efficiency of the actual economic management of enterprises.

\subsection{Relatively unitary organizational structure}

Currently, most enterprises lacking the substantial and targeted economic management system contributes to a more unitary management organization and mode. The business organization lack 
of diversity and flexibility, in practice, cannot handle the problem flexibly. However, in the current market economy, the economic management system and organizational structure of enterprises need to keep abreast with the pace of social development and meet the needs of social development. Most organizations and management systems set the goal of rapid economic development, while seriously ignoring the internal management of enterprises. The consequence of the phenomenon is not only the enterprise management organization's failure to follow the pace of social development needs, but also the ever decreasing economic benefits of enterprises.

\section{Specific measures for enterprises to innovate economic management modes from the marketing perspective}

\subsection{Promoting the pertinence and substantiality of the economic management mode}

As a prerequisite of enhancing the comprehensive competitiveness of an enterprise, the advanced science and technology is an important way to improve the efficiency of enterprise economic management. In marketing, seizing the market and acquiring the latest information of an enterprise rest with the use and reasonable utilization of science and technology to achieve the purpose of promoting the development of enterprise information. In addition, favorable internal development environment, external market environment and the effectiveness of enterprise management model are crucial factors to promote the healthy and orderly development of enterprises. In view of the impertinence and insubstantiality of the internal economic management mode, the enterprise is supposed to adjust the internal economic management system and management model timely in accordance with the marketing environment and its own actual situation, together with introducing the advanced science and technology to achieve the goal of market development and realize the innovation and improvement of the economic management model. From the perspective of marketing, it is an innovation of management mode for enterprises to adjust and correct their economic management mode.

\subsection{Improving the economic management system}

Advanced management concept is the premise for enterprises to formulate economic management mechanism and scientific management technology is the key factor to enhance the comprehensive market competitiveness of enterprises. It is a basic condition to formulate strategic development goals and plans in accordance with their own level of business development and the actual needs of the market, while the rational and effective implementation of strategic management and plans is the substantial requirement. In view of the defects in the internal management system of most enterprises in our country currently, enterprises need to strengthen the measures to formulate and perfect the scientific internal management system from the angle of marketing and innovative management concepts, which can give play to the effectiveness and role of internal management development and act as an important basis for staff to enhance their own ability and binding.

For instance, in the construction management, enterprises need to focus on strengthening the effective and reasonable use of delicacy management. In view of the imperfect internal economic management system, the cost involved in the engineering construction project should be delicately managed. Cost control is the top priority in engineering construction. Whether it is the purchase of construction materials or construction management, it is a necessity to work well on cost control to achieve the scientific control of project construction. Therefore, how to use scientific and delicay management to achieve cost savings is the core of construction management. But the delicacy management and the scientific strategic goal need to rely on the sophisticated management system and the scientific management mechanism, while taking this as the evaluation index to carry on a series of cost control and the construction management work, particularly the introduction of materials management and technology. In the project management, strengthening the material management is an important measure to ensure the construction progress and upgrading the management technology and construction technology are two important aspects to improve the quality of the construction project. Therefore, in the construction of the project, we should actively 
respond to the national call to strengthen the environmental protection of the project construction and actively introduce new technology and management methods.

\subsection{Building scientific supervision mechanisms}

Whatever it is the scientific management of human resources or fine management, enterprises need to adjust and improve the defects in their own management mechanism in time so as to further improve the internal supervision mechanism and management system. In addition, enterprises are following the market demand and their own development goals to adjust and correct the management system, strengthen the relevant supervision system and then give full play to the role and function of the supervision mechanism, that is, the economic management function. In marketing management, once the problem of economic cost price and budget is handled improperly, it will not only affect the work of enterprises in the later stage of audit and quality supervision, but also directly the market competitiveness of enterprises. Therefore, reasonably controlling the cost and strengthening the cost budget mechanism are the key approaches to improving the audit result.

In the process of strengthening and perfecting the management and supervision mechanism, it is necessary to strengthen the risk management in the market competition. No matter in the stage of financing, investing, operating or managing, there are all kinds of potential risks. Therefore, enterprises need to innovate the management mode, formulate strategic planning objectives and improve the management mechanism. Before that, there is a need for the enterprise to take various market risks into account and establish a targeted and substantive risk management mechanism to control market risks at a time.

\subsection{Strengthening human resources training mechanisms}

In the marketing management, the innovation management model and the perfecting management mechanism need to be incorporated with the human resources training mechanism to help the enterprise satisfy the market development needs and provide the solid backing. Human resources do not only play an important role in the internal economic management of enterprises, but also improve the efficiency and quality of internal management. As important members of the human resources management system, both managers and employees should have good personal qualities, and establish a sense of responsibility and management awareness in the actual work to enhance the enthusiasm and proactivity during the work. In the market competition, the scientific management system is as important as the comprehensive ability of the staff. In the development of human resource management and configuration, enterprises need to divide the employees into suitable positions in line with their personality characteristics and ideas so as to ensure that the employees can fully develop their own abilities and enhance their sense of self-responsibility concurrently, and avoid the waste of talented people as well.

Enterprises should adhere to the "people-oriented" management concept and take it as one of the bases of talent management and training, while formulating strategic development goals or building the economic management system. The enterprise needs to stand in the scientific perspective to analyze the actual needs and comprehensive capabilities of employees, while ensuring the effectiveness of the flow of information to strengthen the exchange and communication between employees, so as to achieve the sustainable development of enterprises. The reasonable job arrangement and attention to employees' own needs can help employees obtain satisfaction and happiness in their jobs, which is an innovation to the management mode of employees in enterprises. The enterprises should create a good working environment for employees in the actual management, establish a perfect incentive system and actively introduce incentive mechanism. In addition, in the process of specific personnel training, the enterprises should strengthen the professional ability training and pre-job training for employees, improve the overall quality of employees and give full play to their own professional skills in practical work to improve the actual work efficiency and management service quality. 


\section{Concluding remarks}

There are still many problems in the actual management of enterprises, which requires enterprises to constantly adjust and correct the current economic management system and risk management mechanism in accordance with their actual situation while paying attention to their own economic needs. Hence, the pertinence, scientific, integrity and substance of internal economic management system can be improved and the business efficiency can be enhanced.

\section{References}

[1] L. L. Shen, Enterprise Economic Management Model under the condition of Market economy, Chinese Urban Economy, vol. 18, pp. 131-392, 2011.

[2] B. Li, Study on the standardized strategy of modern enterprise economic management , Oriental Corporate Culture, vol. 19, pp. 203-207, 2014.

[3] Z. Lei, Analysis of enterprise economic management model under the condition of market economy, Chinese High and New Technology Enterprises (in Chinese), vol. 1, pp. 167-168, 2015.

[4] W. Y. Dou, Reflections on enterprise economic management model under the condition of market economy, Shang Li, vol. 10, p. 15, 2013.

[5] W. X. Chen, Study on enterprise economic management model under market economy, Chinese and Foreign Entrepreneurs, vol. 1, pp. 84-86, 2016.

[6] S. J. Hu, An analysis of enterprise economic management model under the condition of market economy, Chinese Business Theory, vol. 67, pp. 32-34, 2016. 